\title{
Ultrafast single-shot diffraction imaging of nanoscale dynamics
}

ANTON BARTY, SÉBASTIEN BOUTET, MICHAEL J. BOGAN, STEFAN HAU-RIEGE, STEFANO MARCHESINI, KLAUS SOKOLOWSKI-TINTEN, NIKOLA STOJANOVIC, RA'ANAN TOBEY, HENRI EHRKE, ANDREA CAVALLERI, STEFAN DÜSTERER, MATTHIAS FRANK, SAŠA BAJT, BRUCE W. WOODS, M. MARVIN SEIBERT, JANOS HAJDU, ROLF TREUSCH AND HENRY N. CHAPMAN

Nature Photonics 2, 415-419 (2008)

In the above article, the authors incorrectly denoted the affiliations of Janos Hajdu. He is affiliated to both the second and third institutions in the address list, that is: the Stanford Synchrotron Radiation Laboratory at the Stanford Linear Accelerator Center (SLAC) and the Laboratory of Molecular Biophysics at Uppsala University. 